\title{
MINORITAS MUSLIM DI CHINA: PERKEMBANGAN, SEJARAH DAN PENDIDIKAN
}

\author{
Ismail Suardi Wekke Rusdan \\ iswekke@gmail.com \\ Diterima: 06 Desember 2016. Disetujui: 21 April 2017 \\ Dipublikasikan: Mei 2017
}

\begin{abstract}
Abstrak
Terdapat bebeberapa teori tentang masuknya agama Islam di China. Perbedaan pendapat tersebut disebabkan oleh kurangnya data yang valid yang ditemukan dilapangan tentang kapan dan dimana pertama kali Islam menyebar di negeri itu.Menurut Jean A. Berli dalam bukunya Islam in China menjelaskan,masuknya Islam di China berlangsung pada abad ke8.Sedangkan apabila berdasarkan pada catatan Chen Yuen dan catatan resmi dari Dinasti Tang menunjukkan bahwa Khalifah Utsman bin Affan sudahmengirim utusan ke China sejak abad ke-7, tepatnya tahun 30 H/651 M. Kedatangan Islam lebib dari 10 abad yang lalu tentu sedikit banyak memberikan dinamika tersendiri bagi perkembangan Cbina. Meski sebagai minoritas, umat Islam di China selalu melibatkan diri dalam proses dealektika sejarah berdirinya negeri tersebut. Babkan tokoh revolusionis yang membawa China dari pemerintahan tiran (Dinasti Manchu) menuju negara Republik. Demokratis adalah seorang tokoh Islam yang bernama Sun Yat Sen. Hadimya Sun Yat Sen dan tokoh-tokoh muslim penting lainya tidak lepas dari kegigihan umat Islam dalam membangun peradaban mereka melalui kultur, sosial, budaya dan pendidikan yang mereka perjuangkan selama berabad-abad. Di sadari atau tidak, kegigihan umat Islam inilah yang secara tidak langsung juga ikutserta dalam menentukean arah gerak. masa depan China yang sekarang ini.
\end{abstract}

Kata Kunci: Minoritas, Muslim China, Perkembangan, Sejarah dan Pendidikan

\section{Pendahuluan}

Islam sebagai agama rabmatan lil alamin sudah sepantasnya bagi pemeluknya (umat Islam) untuk bergerak aktif 
menyebarluaskan ajaranya. Usaha untuk mengajak orang-orang yang belum mempercayai kebenaran dalam Islam dianggap sebagai tugas suci yang mulia. Oleh karena itu,semangat dakwah dan memperjuangkan kebenaran inilah yang telah mendorong umat Islam merasa wajib untuk menyampaikan ajaran-ajaran luhurnya kepada setiap orang dimana mereka berpijak. Ada banyak cara yang dilakukan orang muslim dalam berdakwah, seperti dalam pendidikan sebagai sarana transformasi ilmu pengetahuan ${ }^{1}$, perdagangan, politik, pernikahan serta penaklukan wilayah.

Misi dakwah Islam tidak hanya terbatas melalui jalur penaklukkan wilayah. Hubungan perdagangan internasional juga dapat menjadi perantara penyebaran agama Islam. Seperti halnya penyebaran Islam ke Asia Timur yang terjadi karena hubungan dagang antara China dan Arab. Bahkan beberapa sumber menyebutkan hubungan dagang tersebut sudah terjalin sejak lama sebelum Islam lahir. Kapal-kapal dagang China sering berlayar dan bersandar di pelabuhan Siraf yang terltak di Sungai Eufrat dan pelabuhan lain yang ada di teluk Arab pada sekitar abad ke-5 dan ke-6 M.

Sementara itu, sejarah peradaban umat Islam di Chinadapat ditelusuri sejak masa Dinasti Tang (618-907 M) yang ditandai dengan semakin meningkatnya pedagang Arab dan Persia yang singgah di pelabuhan-pelabuhan China.Sumber lain juga menyebutkan bahwaselama kurun waktu 147 tahun dari tahun 651 M hingga $798 \mathrm{M}$, negara Arab telah mengirim utusannya lebih dari 37 kali ke China. ${ }^{2} \mathrm{Hal}$ itu membuktikan msyarakat China telah mengenal atau setidaknya mereka telah melakukan interaksi dengan orang-orang Islam sejak abad ke-7 M. Selain itu bukti sejarah ini juga menunjukkan penyebaran Islam di China dilakukan secara damai bukan dengan cara peperangan layaknya penyebaran Islam

1 Ismail Suardi Wekke, 'Antara Tradisionalisme Dan Kemodernan: Pembelajaran Bahasa Arab Madrasah Minoritas Muslim Papua Barat', Tsaqafah, 11.2 (2015), 313-32; Ismail Suardi Wekke, 'Religious Education and Empowerment: Study on Pesantren in Muslim Minority West Papua', Miqot, XXXVII.2 (2013), 374-95; Ismail Suardi Wekke and Sanusi Hamid, 'Technology on Language Teaching and Learning: A Research on Indonesian Pesantren', Procedia - Social and Behavioral Sciences, 83 (2013), 585.

${ }^{2}$ Ibrahim Tien Ying Ma, Perkembangan Islam Di Tiongkok (Jakarta: Bulan Bintang, 1979). 
di wilayah Timur Tengah, Afrika dan sebagian Eropa pada masa itu.

Pada perkembangan selanjutnya, dinamika kehidupan umat Islam baik dalam segi kultur, sosial, budaya dan pendidikan terbentuk selama beberapa generasi dibawah dinasti penguasa China seperti Dinasti Sung (960-1279M), Dinasti Yuan (1279-1368 M), Dinasti Ming (1368-1644 M), Dinasti Manchu (1644-1912 M), masa Republik Nasionalis (1911-1949 M), dan masa Republik Rakyat China (1948-sekarang). Dinasati demi dinasti mereka lalui dengan penuh tantangan dan tidak jarang mereka harus berhadapan langsung dengan penguasa karena dianggap tidak memberikan rasa keadilan bagi rakyat. Sebut saja Sun Yat Sen, dia adalah tokoh muslim China yang menggaungkan semngat revolusi karena dianggap pemerintahan Dinasti Manchu bertindak sewenawena. Tidak hanya menggulingkan kekuasaaan yang tidak pro rakyat, revolusi yang ia digaungkan juga membawa China menuju negara yang lebih modern dengan sistem Republik Demokratis.

Disadari atau tidak, China yang sekarang ini menjelma menjadi negara yang diperhitungkan di dunia. Bahkan sebutan baru bagi Negeri Tirai Bambu tersebut adalah The Second of America. Meski demikian, kesuksesan yang dicapai China tidak terjadi secara instant. Karena representasi wajah China yang kita lihat dewasa ini merupakan representasi dari sejarah panjang yang didalamnya terdapat perjuangan umat Islam yang tidak dapat kita abaikan begitu saja, meski secara kuantitas mereka adalah masyarakat yang minoritas.Dinamika inilah yang menarik untuk kita telisik tentang bagaimana perkembangan kultur, sosial, budaya dan sistem pendidikan umat Islam di China dari satu dinasti ke dinasti lain.Tulisan ini mencoba merangkai beberapa teori atau pendapat para ahli sejarah yang terdapat di beberapa artikel jurnal, buku dan tesis dengan harapan dapat memberikan gambaran tentang sejarah, perkembangan dan pendidikan minoritas muslim di China.

\section{Teori Penyebaran Islam di China}

Proses Masuknya Islam di China berbeda dengan proses penyebaran Islam di Timur Tengah, Afrika atau sebagian wilayah Eropa lainya. Di China, Islam masuk dengan cara yang lebih halus 
tanpa ada sebuah peperangan. Para pakar sejarah menyebutkan, setidakya terdapat tiga (3) teori masuknya Islam di daratan China yaitu:

Teori Pertama, Islam masuk ke China dibawa oleh para sahabat yang diutus langsung oleh Nabi Muhammad SAW. Diutusnya beberapa sahabat memang merupakan salah satu misi dakwah dari Rasulullah. Kita tahu bahwa jarak antara Makkah dengan China sangat jauh. Pada masa itu hanya ada dua kemungkinan untuk sampai ke negeri China yaitumelalui jalur daratatau melalui jalur laut. Kedua jalur tersebut memiliki resiko dan bahaya tersendiri. Dari kedua jalur yang ada, jalur darat yang lebih suka digunakan oleh para sahabat untuk menyampaikan misi dakwahnya. Oleh karena itu perkembangan Islam disebelah barat China lebih cepat jika dibandingkan dengan wilayah China bagian timur. Hipotesa ini semakin diperkuat dengan adanya makam para sahabat di daerah barat bagian China. Adapun jalur yang mereka lalui biasa disebut dengan "Jalur Sutra". ${ }^{3}$

Teori Kedua, seperti halnya penyebaran Islam di Idonesia, beberapa pakar sejarah menjelaskan penyebaran Islam di China dilakukan melalui perkawinan. Fakta sejarah ini dapat kita telusuri melalui wajah-wajah mereka yang memiliki kemiripan dengan wajah orang-orang Arab, Turki, Persi, Afganistan, Uzbekistan atau Pakista. Struktur biologis wajah mereka menunjukkan bahwa terdapat percampuran ras dengan masyarakat yang tinggal di Timur Tengah yang memiliki ciri khas muka putih kemerahan dengan hidung yang sedikit agak mancung. ${ }^{4}$

Perkawinan campuran ini tidak hanya mendorong jumlah/kuantitas umat Islam di China.Lebih dari itu, generasigenerasi tersebutjuga memberikan sumbangsih terhadap kualitas umat Islam China dimasa yang akan datang. Terbukti muslim China masih mampu mempertahankan nilai-nilai ajaran agama luhur merekameski hidup di bawah tekanan daribeberapa dinasti di China. Ketaatan mereka tergambar jelas melalui nama-nama

\footnotetext{
${ }^{3}$ Aan Wang Seng, Rahasia Kegemilangan Islam Di China (Selangor: LA Khauf Marketing, 2007).

${ }^{4}$ Asmanidar, 'Potret Tamaddun Islam Di Negeri Tirai Bambu: Mulai Dari Masa Dinasti Tang Hingga Republik China', Jurnal Ilmiah Islam Futura, 14.2 (2015), 195.
} 
mereka yang terinspirasi dari dunia Islam seperti $M a$ Ho, Sulaiman Ding, Ma Hudan lain sebagainya. Bahkan nama-nama tersebut masih dapat kita jumpai hingga saat ini.

Teori Ketiga, melalui jalur perdagangan Lada. Rute perjalanan ini digunakan oleh para pedagang Arab yang melakukan perjalananya perdaganganya melalui laut. Para pedagang tersebut menjual barang dagangannya di pelabuhan-pelabuhan yang terletak di Selatan China terutama di kawasan Bandar Canton. Salah satu bukti sejarah tentang kedatangan para saudagar tersebut adalah adanya masjid-masjid kuno di daerah Guangzhou. Begitu juga terdapat peninggalan batu nisan yang memiliki ukiran dengan kaligrafi huruf Arab yang sangat Indah di tempat tersebut. selain itu, jalur ini juga digunakan oleh Laksamana Cheng Ho sebagai jalan untuk melancarkan ekspedisinya ke negera-negara lain. Bahkan hingga pedagang dari India sekalipun juga menggunakan jalur tersebut sebagai jalur untuk pergi ke China. ${ }^{5}$

Ketiga teori tentang masuknya Islam ke China menunjukkan bahwa tidak ada peperangan/kekerasan yang terjadi selama proses islamisasidi negeri tersebut. Dengan model penyebaran Islam seperti itu, tentu model Islam di China akan memberikan corak tersendiri tentang bagaimana kehidupan sosial budaya msyarakatnya. Hampir sama dengan masyarakat Islam di Indonesia, masyarakat Islam di China juga memiliki ciri khas tersendiri, yakni luwesnya akulturasi budaya antara nilai-nilai agama yang bercorak arabsentris dengan budaya asli setempat. Perpaduan budaya inilah (akulturasi) yang menjadi Islam di Chinabegitu unik. Karena mereka berusaha untuk menyeimbangkan antara kewajiban (tuntutan agama) dan budaya sebagai identitas bangsa. Perpaduan apik ini dapat terlihat jelas melalui kultur budaya mereka baik melalui nama-nama yang mereka gunakan, bahasa yang digunakan, pendidikan bahkan hingga cara berpakaian mereka.

\section{Tahapan Masukknya Islam di China}

Jean A. Berlie dalam bukunya Islam in China: Hui and Uygghurs Between Modernization and Sinicization menjelaskan bahwa tersebarnya Islam di china melalui tiga (3) tahap.

\footnotetext{
${ }^{5}$ Ibid.
} 


\section{Gelombang Pertama, (Abad ke 8-14 M)}

Kerjasamanon-commercial pertama antara pemerintahChina denganIslam terjadi pada abad kedelapan. Tercatat pada tahun 713 M seorang utusan muslim meninggalkan Ferghana salah satu daerah di Uzbekistan.Sementara itu pada kisaran abad kesembilan, salah seorang saudagar dari basrah yang bernama Ibn Wahab diterima oleh khaisar Yizong (859-873 M), sang kaisar tertarik dengan koleksi megah yang ia bawa. Selanjutnya pada tahun 1345 M Ibnu Batutah mengunjungi Cantonsebagai pusat pelabuhan perdagangan orang-orang Arabdi China. Abad ke-8 hingga ke-14 inilah Islam mengalami perkembangan yang sangat pesat tepatnya dibawah kekaisaran Yizong dan Ming. Arus perdagangan juga semakin ramai karena para pedagang dari Arab mampu menggeser dominasi Portugis yang sebelumnya sempat menguasai pusat perdagangan di Macao. ${ }^{6}$

\section{Gelombang Kedua Sufi (abad ke 17-18 M)}

Gelomba kedua masuknya Islam di China melaluiajaran suffisme terjadi sekitar abad ke $17 \mathrm{M}$ hingga $18 \mathrm{M}$. Pada tahun 1820-1876 M terjadi sebuah pemberontakandi sebelah utara dan barat daya China dan sekaligus menjadi akhir dari berdirinya negara Islam di Yunan. Raja Sulaiman (Du Wenxiu nama panggilan Chinanya) meninggal pada momentum tersebut. Pada kurun waktu yang sama, seorang yang berkebangsaan perancis bernama Garnier (1839-1873 M) menjelaskan bahwa Islam masuk ke China pada msa itu tidak lepas dari peran penting Syech Sulaiman yang berasal dari Dali. Dengan paham zahiriyahnya, ia berusaha menyebar luaskan pahamnya di daerah Gansu. Sementara itu Ningxia (tetangga dekat dari Gansu) juga terdapat seorang tokoh spirutual yang cukup berpengaruh dengan paham suffismenya yaitu Master Ma Hualong (1820-1871 M). ${ }^{7}$

\section{Gelombang ketiga (abad ke-19) saat ini}

Gelombang ketiga masuknya Islam di China merupakan reaksidari ajaran sufisme yang ditandai dengan berakhirnya abad

\footnotetext{
${ }^{6}$ Jean A Berlie, Islam in China: Hui and Uygghurs Between Modernization and Sinicization (Bangkok: White Lotus, 2004). 1-2.

${ }^{7}$ Ibid, 2.
} 
ke-19. Terdapat ungkapan unik untuk menandai arus penyebaran Islam pada masa ini yaituthe new ofrelegion (agama baru) yang dimotori oleh Ma Wanfu (1849-1934 M). Model dakwanya sendiriterinspirasi oleh doktrin sufisme yang dia anut. Selain itupaham dan gerakan dari Ma Wanfu juga sering disebut dengan paham dan gerakan anti ortodoks. ${ }^{8}$ Meski paham sufiesme (the new of relegion) terbilang lebih liberal dan fleksibel jika dibandingkan dengan ajaran Islam sebelumnya, tidak menjadikan Islam pada masa itu menjadi agama yang mayoritas. Memang pemeluk Islam meningkat jika dibandingkan dengan masa-masa sebelumnya.

\section{Periodesasi Perkembangan Islam di China}

Perkembangan Islam di China dari masa ke masa mengalami pasang surut. Masa rintisan hingga masa perjuangan mempertahankan keyakinanan sudah mereka jalani lebih dari 10 abad lamanya. Untuk mendapatkan gambaran tentang kehidupan masyarakat muslim China secara hollistic, maka mengetahui sejarah/periodesasi perkembangan Islam dari dinasti Tang (618709 M) hingga masa Republik Rakyat China (masa sekarang) merupakan hal yang sangat penting untuk diketahui. Berikut sejarah perkembangan Islam di China berdasarkan periodesasi imperium yang berkuasa pada masa itu:

\section{Masa Dinasti Tang (618-709 M)}

Seperti yang telah disinggung pada pembahasan sebelumnya, terdapat perbedaan pendapat terkait masuknya Islam ke China. Apabila kita mengacu pada teori tahapan proses masukknya Islam di China Jean A. Berlie, masuknya Islam pertama kali di China pada abad ke-8 M. Namun menurut catatan resmi dari Dinasti Tang (618-905 M), serta catatan yang sama dalam $a$ brief history of the introduction of Islam to China yang ditulis oleh Chen Yuen menjelaskan bahwa utusan pertama yang dikirim oleh Utsman bin Affan sekitar tahun kedua dari pemerintahan Kaisar Yong Hui (30 H/651 M). ${ }^{9}$

Pendapat Chen Yuen diperkuat dengan catatan resmi dari pihak China (Chinese Chornicles) yang menjelskan bahwa sejak abad

\footnotetext{
${ }^{8}$ Ibid, 2-3.

${ }^{9}$ Ma. Loc.cit
} 
ke-5 $\mathrm{M}$ terdapat riwayat hubungan dagang antara ChinadanArab. Pada masa itu banyak armada kapal dagang dari China yang melakukan pelayaran menuju teluk Persi, muara sungai Eufrat dan Trigis. Dinasti Sui (605-618 M) sebagai pendahulu Dinasti Tang membenarkan pernyataan tersebut dalam sebuah riwayat literasinya. Oleh karena itu, apabila Chen Yuen menyatakan bahwa Islam pertama kali masuk ke China pada abad ke-7 memiliki alasan historis yang cukup kuat. Karena antara China dan Arab telah melakukan interaksi jauh sebelum Islam lahir di Makah.

Fakta lain juga menyebutkan, Dinasti Tang di China dibangun oleh Li Yuan yang dipanggil dengan Kaisar Tai Tsu (618626) M), digantikan oleh putranya yang bernama Li Shin Min yang dipanggil dengan Kaisar Tai Tsung (627-649 M) yang juga disebut sebagai masa perkembangan kebudayaan, kesenian dan kesusastraan di China. Pada kurun waktu yang sama, terdapat sebuah hadits dari Nabi Muhammad (570-632 M) yang begitu terkenal yakni: Uthulubul ílma walau bil shini (Tuntutlah ilmu walau ke negeri China). Penyebutan China dalam hadits Nabi tersebut menunjukkan telah ada sebuah interaksi sebelumnya antara China dengan Arab. Oleh karena itu ketika Nabi Muhammad SAW menggunakan kiasan China sebagai semangat untuk menuntut ilmu, masyarakat Arab sudah familiar dengan nama negeri tersebut.

Pada Dinasti Tang, terdapat tempat-tempat yang disediakan khusus bagi orang-orang asing di kawasan Bandar Chow (Kanton), Chuan Chow dan Chang Chow yang terletak di Kwantung dan Fukien. Adapun pedagang yang mendominasi tempat-tempat tersebut adalah adalah para saudagar dari Arab yang sering mereka panggil dengan sebutan Tashih.Selain itu terdapat pula panggilan Yui atau singkatan dari nama Yusuf yang memiliki arti penyiar Islam sama dengan nama/gelar Sa'ad. Yusuf dan Sa'ad sendiri menunjukkan tauladan seorang muslim yang penggunaanya memiliki dampak psikologis yang cukup besar dalam masyarakat Muslim China saat ini. Fakta-fakta sejarah ini semakin membuktikan bahwa Islam datang pertama kali ke China sejak abad ke- $7 .^{10}$

\section{Masa Dinasti Sung (960-1279 M)}

${ }^{10}$ Ma. Op.cit, hal.31 
Chou Kuang Yin, pendiri dari Dinasti Sung terkenal dengan sebutan Kaisar Tai Tsu (960-796 M) berusaha untuk memulihkan kehidupan ekonomi masyarakat pada masa itu. Sang kaisar dan para pengikutnya berjuang keras untuk dapat menarik minat saudagar Arab dan Persi dengan menawarkan berbagai fasilitas beserta jaminankeamanannya. Mereka sengaja untuk membentuk lembaga khusus seperti departemen perdagangan yang bertugas untuk mengawasi kelancaran ekspor-impor. Selain itu depertemen ini juga bertugas untuk memasarkan produk-produk khusus yang merupakan komoditi monopoli pihak pemerintah, sembari mengawasi keamanan para pedagang yang keluar masuk pelabuhan. Alhasil, para saudagar dari Arab dan Persi kembali ramai mengunjungi bandar-bandar dagang sepanjang pesisir China pada setiap musimnya. Adapun bandar-bandar yang terkenal ramai dikunjungi oleh saudagar-saudagar Arab dan Persi adalah Bandar Kwang Chou (Katon) yang berada di wilayah Kwantang dan Bandar Chung Chow yang berada di wilayah Fukien. ${ }^{11}$

Jasa yang paling besar terhadap tata kelola perdagangan ini tidak lepas dari peran seorang pria keturunan Arab bernama $\mathrm{Pu}$ Shou Keng (Abu Bakar atau Abdul Syukur sebelum dirubah dalam ejaan bahasa China). Pada awalnya ia hanya ditugaskan untuk mengurusi kepentingan orang-orang Arab yang ada di China, namun dalam perkembanganya ia menjabat sebagai Komisaris Tinggi Angkatan Laut yang bertugas untuk memelihara dan menjamin lalu lintas kapal dagang dari ancaman para perompak. Terakhir, ia diberi kepercayaan sebagai kepala dinas perdagangan. Karena besarnya jasanya dalam memajukan perekonomian China, ia rela menghabiskan hampir 40 tahun sisa hidupnya untuk kemajuan negeri China. ${ }^{12}$

Karena tata kelola yang diterapkan oleh pemerintahan Dinasti Sung sangat hebat, terdapat peningkatan jumlah saudagar yang berkunjung ke China dari tahun ke tahun. Meski pada perkembangannya para pedagang ingin meneruskan pelayaranya menuju Jepang dan Korea, namun China masih menjadi tempat tujuan utama mereka. Pada umumnya para pedagang yang singgah di China sangat betah dengan iklim dan kultur sosial masyarakat

\footnotetext{
${ }^{11}$ Asmanidar. Op.cit, hal.197

${ }^{12}$ Ma. Op.cit, hal.53
} 
China. Iklim di China sangat memungkinkan bagi para pendatang untuk memiliki kesempatan-kesempatan dagang yang menguntungkan, ${ }^{13}$ ditambah lagi dengan sikap penduduknya yang sangat ramah-tamah. Iklim yang sedemikian rupa, tidak mengherankan apabila banyak diantara mereka para pendatang yang betah dan menetap di China dengan jangka waktu yang lama, bahkan tidak kembali lagi ke negara asal mereka dengan menikahi penduduk setempat hingga memiliki keturunan.

\section{Masa Dinasti Yuan (1279-1368 M)}

Periode terakhir pemerintahan Dinasti Sung menunjukkan ketidakstabilan pemerintahan dengan semakin merajalelanya korupsi. Ditambah dengan hadirnya Jenghiz Khan (1162-1227 M) dengan pasukkan yang hebat menaklukkan berbagai wilayah Asia, termasuk China. Pada tahun 1127 M Dinasti Sung yang ada di sebelah utara tumbang di bawah tentara Jenghiz Khan. Meski para pejuang China mencoba untuk mempertahankan serangan tentara Mongol, namun usaha tersebut tetap tidak membuahkan hasil bahkan Dinasti Sung Selatan juga ikut runtuh pada kisaran tahun 1127-1279 M. Dengan berakhirnya Dinasti Sung maka terbentuklah dinasti baru di bawah kekuasaan bangsa Mongol yang bernama Dinasti Yuan.

Dinasti Yuan sendiri memiliki corak pemerintahan yang penuh tirani dan hanya mampu bertahan selama 89 tahun. Bangsa Mongol seakan tahu bagaimana cara mengendalikan bangsa China dengan memiliki wilayah membentang yang sangat luas. Mereka tidak diperkenalkan dengan hak asasi dan dipaksa untuk selalu tunduk dan patuh kepada penguasa yang tiran. Sadar dengan keterbatasan yang mereka miliki ditambah dengan batas teritorial China yang sangat luas, memaksa bangsa Mongol untuk meminta bantuan tenaga-tenaga ahli dari wilayah Asia Barat untuk

\footnotetext{
${ }^{13}$ Sejak lama bangsa China dikenal sebagai bangsa yang rajin, kuat dalam bekerja dan suka berdagang. Oleh karena itu tidak bisa dipungkiri, dimanapun mereka berada, mereka selalu mampu mengubah masyarakat sekitar menjadi sebuah kawasan dengan berbagai aktifitas perdagangan yang membuat perkembangan dan kemajuan masyarakat yang ada di dalamnya. Lihat, Aan Wang Seng, Biar Orang China Pimpin Islam (Selangor: Kemilau Republika, 2011).
} 
membantu mengurus keadministrasian diwilayah yang baru dibentuk tersebut. ${ }^{14}$

Meski terkenal sebagai pemerintahan yang tiran, justru pada DinastiYuan ini umat Islam mendapatkan tempat yang istimewa dalam struktur pemerintahan. Hal ini dikarenakan oleh politik advisori yang diterapkan oleh bangsa Mongol. Mereka terpaksa menggunakan orang-orang yang cakap serta yang dipandang mampu dalam mengelola pemerintahan yang mereka ambil dari wilayah taklukkanya yang mayoritas beragama Islam. Oleh karena itu banyak posisi penting yang berhasil dipegang oleh orang Islam pada masa itu. Sambutan hangat Dinasti Yuan terhadap umat Islam ini yang mendorong orang Islam pribumiChina lebih produktif dan proaktif dalam menyebarkan misi ilahiyahnya. Sehingga lambat laut ketertarikan penduduk pribumi (China) terhadap Islam juga semakin meningkat. Bahkan banyak masjid yang dibangun di beberapa sudut kota pada era dinasti ini. Inilah alasan kenapa pada masa Dinasti Yuan terdapat ungkapan "dimanapun berada, di bawah kolong langit, ada orang Islam pada masa Dinasti Yuan". ${ }^{15}$ Karena memang kehidupan beragama (terutama Islam) sangat di junjung tinggi oleh Dinasti Yuan.

Pada Dinasti Yuan ini, tidak ada kecemburuan sosial antara para pendatang muslim dengan muslim pribumi. Mereka menjalin keharmonisan layaknya sahabat Muhajirin dan Ansor di Madinah. Mereka sama-sama melaksanakan shalat berjamaah secara bersamaan tanpa ada perbedaan ras maupun bangsa. Bahkan sebagai bentuk keakraban mereka, orang-orang Islam dari Arab memiliki panggilan tersendiri dengan sebutan Tashib atau Semit (disingkat dengan Sem). Ada juga yang dipanggil dengan nama HoiHoi dan pada perkembanganya menjadi Hui-Hui (Uighurs). ${ }^{16}$ Panggilan Sem ditujukkan untuk surat-surat resmi, sementara panggilan yang lain untuk nama panggilan sehari-hari. Keharmonisan kehidupan beragama lintas bangsa inilah yang terbangun pada Dinasti Yuan.

\footnotetext{
${ }^{14}$ D.G.E Hall, Sejarah Asia Tenggara (Surabaya: Usaha Nasional). 139-141.

${ }^{15}$ Lihat dan bandingan dengan uraian Asmanidar. Op.cit, hal.200

${ }^{16}$ Marshall Broomhall, Islam in China: A Negletged Problem (New York: Paragoon Book Reprint Corp, 1966). 167.
} 
Banyak muncul tokoh-tokoh intelektual dari kalangan Islam pada masa Dinasti Yuan. Diantaranya adalah dua orang yang terkenal dalam bidang persenjataan militer (meriam) yakni Ismail al-Syami dan Alaudin al-Mufari. Keduanya merupakan imigrant dan bukan penduduk asli pribumi China. Mereka merupakan orangpertama yang menggunakan bubuk misiu (gun powder) untuk melontarkan bola-bola meriam guna menghancurkan tembok/benteng pertahanan para musuh. Dinasti Yuan sendiri pernah menggunakan karya mereka untuk menghancurkan benteng pertahanan Hsiang Yang di Provinsi Hupel. Bahkan pada perkembangan selanjutnya, salah satu sang inovator meriam tersebut yakni Alaudin al-Mufari diangkat menjadi Deputi Wan $\mathrm{Hu}$ (wakil panglima yang membawahi pasukan sekitar tujuh ribu prajurit). Sementara Ismail al-Syami memangku jabatan sebagai Kepala Pengawas pada pabrik pembuatan senjata. ${ }^{17}$

Meski umat Islam mendapat sambutan baik untuk ikut andil dalam struktur pemerintahan dan mengembangkan syiar Islam, namun penindasan dan sistem pemerintahan yang tiran tidak bisa dibiarkan oleh umat Islam. Masyarakat China pada masa itu dipaksa untuk hidup dibawah tekanan dan penderitaan selama 89 tahun dibawah kekuasaan Dinasti Mongol. Faktor inilah yang menyebabkan terjadi pemberontakan oleh kaum pioner Islam di China terhadap Dinasti Yuan.

Perjuangan umat Islam di China semakin mendapatkan momentum ketika mereka mendapat dukungan dan bantuan dari pasukan Han. Aliansi pemberontakan tersebut dipimpin oleh Genderal Kok Tze Hin. Dia adalah seorang muslim, namun pada akhir peperangan iya menyerahkan pimpinan revolusi pada menantunya yakni Chu Yuan Chang. Dinastu Yuan pun tumbang ditangan Genderal Kok Tze Hin yang ditandai dengan diangkatnya Chu Yuan Chang sebagai kaisar pertama dari Dinasti Ming. Dengan panggilan kebesaranya Kaisar Hung Wu (namun sejarah lebih mengenalnya dengan sebutan Kaisar Chu Yuan Chang atau Kaisat Chu), ia berusaha untuk memberikan perubahan pada Negari Tirai Bambu di bawah kepemimpinannya. Istrinya yang seorang muslimah juga ikut diumumkan menjadi ratu dan

${ }^{17}$ Hall.Op.cit, hal.123. 
mendapat jukukan sebagai Ratu Ma atau Empress $M a{ }^{18}$ Pada Dinasti Ming inilah Islam mendapat perhatian lebih jika dibandingkan pada masa Dinasti Yuan. Sehingga, pada beberapa sektor, Islam mengalami kemajuan yang cukup pesat.

\section{Masa Dinasti Ming (1368-1644 M)}

Dinasti Ming memiliki arti "gilang gemilang" atau "terang benderang". Memang penamaan dinasti tersebut perlu dipertanyakan bagi masyarakat China non-muslim, namun bagi orang Islam pertanyaan ini cukup jelas dan memiliki makna yang mendalam. Hal ini ada kaitanya dengan penamaan kota Madinah alMunawarah dari yang sebelumnya bernama kota Yastrib. Madinah al-Munawarh sendiri memiliki arti "terang benderang". Inilah alasan utama kenapa Dinasti Yuan diganti dengan nama Dinasti Ming yang memiliki konotasi sama dengan penamaan kota Madinah yang ada di Arab. Dengan melihat dari penamaan dinasti ini saja kita bisa medapatkan gambaran bagaimana masa depan Islam di China di bawah kepemimpinan Kaisar Chu. Oleh karena itu wajar apabila banyak sumber sejarah yang menyebutkan bahwa Islam memperoleh perkembangan yang pesat pada masa Dinasti Ming. Tidak hanya bagi para pendatang muslim dari semenjung Arab, akan tetapi bagi keturunan Han (keturunan yang paling mendominasi negeri China) juga mendapatkan perhatian besar.

Kecintaan Kaisar Chu Yuan Chang terhadap Islam terlihat sangat jelas ketika keputusan pertamanya setelah berhasil menaklukkan Kota Nanking dengan membangun masjid raya. Terdapat dekorasi sajak 100 huruf dalam tulisan China yang menggambarkan Islam secara universal. Adapun isi sajak tersebut adalah:

Kitab suci menerangkan dengan jelas tentang permulaan alam semesta. Nabi yang mengajarkan agama itu lahir di di Barat Besar. Ia menerima wahyu suci yang berjumlah 30 juz. Memberikan pencerahan kepada banyak orang. dia itu adalah guru bagi beribu raja dan kaisar, dan pemuka seluruh Nabi. Ia itu membantu revolusi yang dianugrahkan langit ini untuk mensyiarkan dan melindungi negeri dan

${ }^{18}$ Ma. Op.cit, hal. 53. 
rakyat. Sembahyang dilakukan lima kali sehari untuk mendekatkan diri kepada Sang Maha Pencipta dan untuk mencapai kebahagiaan di dunia. Agama tersebut sangat santun terhadap orang yang melarat dan melindungi manusia dari kekacauan. Ia melukiskan hidup pada hari kemudian dan kemenangan di situ. Ia mengajarkan cinta yang menyeluruh di bawah nangan langit. Semua ajarannya berawal dari semenjak alam diciptakan dan akan tetap hidup selama-lamanya. Agama itu punya kekuasaan Maha Perkasa untuk membasmi ajaran-ajaran iblis, menyimpang dan menyesatkan. ${ }^{19}$

Sajak-sajak dalam bahasa China tersebut mempertegas bahwa kaisar Chun Yuan Chang sangat mencintai dan menjujung tinggi Islam. Bahkan pada generasi setelahnya, masjid raya tersebut diperluasa dan diperbesar oleh Kaisar Sheh Tsung (1522-1566 M) dan mendapat sebutan sebagai Masjid Chin Juieh (Masjid Pencerahan Murni).

Pada masa ini, terdapat satu tokoh muslim yang tidak hanya dihormati oleh masyarakat China namun beberapaa negara Asia yaitu Laksamana Cheng Ho. Memiliki nama asli Zheng He (1371-1435), ia lebih terkenal dengan sebutan Ma Sanbao (salah satu nama Muslim di China yang sering diguanakan). Dialah yang sebenarnya patut untuk mendapat gelar "The Real of Sinbad". Laksamana Haji Muhammad Cheng Ho lahir di daerah Kumming (wilayah Yunnan). Awalnya ia memiliki nama Ma Ho, akan tetapi Kaisar Chu Yuan Chang menukar namanya menjadi Cheng Ho ketika pasukan Dinasti Ming menyerang pihak Mongol baik didalam maupun luar negeri. ${ }^{20}$

Laksamana Cheng Ho telah mendedikasikan hidupnya di lautan yang luas. Setidaknya dia pernah memimpin 7 kali ekspedisi pelayaran dengan pelayaran pertamanya pada tahun 1405 M. ${ }^{21}$ Pelayaran yang dilakukanya itu benar-benar mempererat hubungan antara China dengan penguasa-penguasa di Asia tenggara, Afrika dan Arab. Teerhitung lebih dari 30 raja, duta dan

\footnotetext{
${ }^{19}$ Ibid, 126.

${ }^{20}$ Ibid, 137.

${ }^{21}$ Seng, Rahasia Kegemilangan Islam Di China. Hal. 85
} 
para sultan melawat ke China karena kunjungan Cheng Ho. Ia telah meninggalkan kesan yang mendalam tidak hanya tempattempat yang pernah ia singgahi, namun juga bagi masyarakat China baik muslim maupun non-muslim.

Meski sumbangan Dakwah untuk menyiarkan ajaran Islam jarang disematkan kepada laksaman Cheng Ho dan seakan lebih mengedapankan misi maharaja yang ia emban, namun ia telah meninggalkan banyak pengikut (murid) di tempat-tempat yang pernah ia singgahi. Bahkan untuk mengenang jasa-jasanya terdapat banyak monumen yang dibangun di daerah Asia Tenggara seperti di Malaka, Kuala Trengganu, Ipoh, Pulau Pinang, Bankok (Thailand), Semarang (Indonesia), Sri Lanka dan masih banyak lagi daerah lainya. Semangat yang ada pada diri laksamana Cheng Ho menunjukkan ia tidak hanya memiliki keyakinan yang sangat kuat tentang Islam, Laksamana Cheng Ho juga memiliki jiwa loyalitas terhadap negerinya. Hubungan timbal balik yang harmonis ini juga tidak lepas dari peran dinasti yang berkuasa pada saat itu untuk memberikan ruang dan apresiasi kepada umat Islam.

\section{Masa Dinasti Manchu/Qing (16441912 M)}

Nurhachi atau bisa disebut dengan nama Chin Khan (1616-1627 M) merupakan penguasa dari wilayah Manchuria pada tahun 1616 M. Wafat pada tahun 1672 M Chin Khan digantikan oleh Huang Tai Chi (1627-1635 M). Sebagai kaisar penerus, Huang Tai Chi mengangkat dirinya sendiri sebagai kaisar dengan nama Dinasti Ching pada tahun 1635 M. Dinasti inilah yang belakangan dikenal dengan sebutan Dinasti Manchu dengan Kota Mukden sebagai ibu kota pemerintahanya. ${ }^{22}$

Munculnya Dinasti Manchu tak lain karena kemelut yang terjadi pada Dinasti Ming menjelang tahun 1644 M. seorang tokoh yang bernama Li Tzu Cheng berhasil menghimpun pasukan dari kaum bandit serta membuat kekacauan dan kerusuhan. Pada waktu itu genderal dari Dinasti Ming yaitu Wu San Kwet tidak mampu menghadapi kemelut yang terjadi yang memaksa ia harus meminta bantuan pasukan Dinasti Ching dari Manchuria untuk menumpas para pemberontak tersebut. Namun sayangnya pasukan Manchu

\footnotetext{
${ }^{22}$ Asmanidar. hal. 202.
} 
justru ingin menguasai Dinasti Ming setalah berhasil mengusir para bandit tersebut. Untuk yang kedua kalinya, Jenderal Wu San Kwet tidak berdaya dan pada akhirnya Dinasti Ming runtuh ditangan pasukan Manchu. ${ }^{23}$

Apabila berbicara posisi umat Islam pada masa itu, sudah jelas sikap umat Islam China mayoritas akan menentang pendudukan tentara Manchu. Legitimasi Islam yangtelah diberikan Dinasti Ming pada masa sebelumya memaksa mereka melakukan perlawanan untuk mengusir tentara Manchu dari wilayahnya. Beberapa kali terjadi kontak senjata setelah gagal melakukan perundiangan perdamaian. Ketegangan ini terus berlanjut dan memaksa dari masing-masing pihak untuk membuat konspirasi yang saling menjatuhkan. Orang Islam membuat jargon: "Hancurkan kekuatan Manchu dan bangun gerakan Ming". Sementara di pihak Manchu juga tidak mau kalah dan membuat semboyan: "Hancurkan para kaum perusub Muslim".

Sebagai upaya umat Islam China mengusir kekuasaan kekaisaran Manchu, mereka mengirim utusan ke Kota Peking untuk melakukan perundingan dengan pihak Manchu, namun usaha tersebut tetap tidak menemukan titik temu. Sejak itulah perlawanan menggunakan senjata dilakukan oleh kaum muslim tersebar yang luas diberbagai daerah selama lebih dari dua abad. Tercatat sejak masa terakhir dari pemerintahan Kaisar Shun Chih (1644-1661 M) hingga masa tumbangnya Dinasti Manchu pada tahun 1912 M, banyak pertempuran yang berlangsung dengan umat Islam. Pada pemerintahan Dinasti Manchu ini umat Islam tidak mengalami perkembangan yang berarti, hanya ada penindasan dan upaya-upaya untuk melepaskan diri dari jeratan penguasa Manchu. ${ }^{24}$

\section{Masa Republik China (1912 M-Sekarang)}

Pada masa kekuasaan Dinasti Manchu/Qing, Islam mengalami masa-masa yang paling sulit dengan kebijakan anti Islam yang diterapkan oleh kekaisaran tersebut. Akibatnya banyak sekali pemberontakan yang terjadi, salah satu pemberontakan yang terkenal adalah pemberontakan Yunnan Islam. Pemberontakan

${ }^{23}$ Ma.Op.cit, hal.164.

${ }^{24}$ Asmanidar. Op.cit, hal.203. 
demi pemberontakan terjadi karena sejarah mencatat imperium Manchu telah memusnahkan lebih dari dua juta muslim hanya dalam kurun waktu 12 tahun. Umat Islam juga pernah dibuang ke luar daerah kekuasaan Dinasti Manchu karena dianggap telah mengganggu kestabilan keamanan pada masa itu. ${ }^{25}$ Umat Islam berusaha untuk sabar menerima segala bentuk diskriminasi dan kekerasan yang dilakukan oleh Dinasti Manchu. Justru cobaan demi cobaan tersebut membuat mereka lebih iamn dan taqwa. Umat Islam baru bisa bernafas lega ketika runtuhnya Dinasti Manchu sekaligus sebagai tanda Era Baru (masa republik) kehidupan China yang lebih modern.

Runtuhnya Dinasti Manchu pada kisaran tahun 1911-1912 M, membuat umat Islam mendapatkan hak-hak mereka kembali. Bahkan didalam konstitusi nasional China, seperti halnya dengan proklamasi Kowmintang dengan jelas telah menjamin kebebasan beragama. Umat Islam mendapat pengakuan secara resmi didalam konstitusinya bahwa China mengakomodir dan memberikan hak kepada wakil-wakil Muslim untuk menempati kursi Majelis Nasional yang dipilih oleh masyarakat Muslim China. ${ }^{26}$

Meski minoritas, umat Islam pada masa ini dipandang sebagai salah satu unsur penting yang dari terbentuknya sebuah Republik Nasionalis Cina yang dipimpin oleh Dr. Sun Yat Sen. Oleh karena itu umat Islam berperan aktif dalam kehidupan politik pada masa itu. Kondisi tersebut memberikan kesempatan bagi umat Islam China untuk membangun dan mengembangkan aspek budaya, ekonomi dan sosial. Terbukti, pada masa itu pula banyak lahir para cendekiawan muslim dan pendidikan Islam di China juga berkembang sangat pesat.

Secara kronologis, terjadinya Revolusi China dimulai ketika China masih berperang melawan Jepang (1894-1895 M). kesempatan tersebut tidak disia-siakan oleh Dr. Sun Yat Set untuk mengadakan gerakan merebut kembali Canton yang dijadikan sebagai pusat revolusi. Meski demikin, usahanya ini tidak langsung membuahkan hasil, karena beberapa kali umat Islam dan masyarakat China harus menerima pil pahit atas kegagalan demi

\footnotetext{
${ }^{25}$ Raphael Israeli, Islam China (United States of America: The Lexington Books, 2002). hal. 43-46.

${ }^{26}$ Ma. Op.cit, hal. 256.
} 
kegagalan yang mereka peroleh. Bahkan pada 9 Oktober 1911, salah satu gudang persenjataan salah satu kelompok revolusi China meledak akibat dibom oleh tentara Manchu. ${ }^{27}$

Satu hari pasca ledakan gudang senjata (10 Oktober 1911 $\mathrm{M}$ ), terjadi pertempuran yang sangat hebat ketika hendak ingin merebut Kota Whucang atau lebih dikenal dengan sebutan WhucangDay, Double Ten Nineteen Eleven. Tepat pada tanggal 12 Oktober 1911 M, hampir seluruh provinsi yang dikuasai oleh Dinasti Manchu berhasil direbut oleh pasukan revolusionis. Dari 18 jumlah total provinsi yang dikuasai oleh Dinasti Manchu, hanya dua provinsi yang masih mampu dipertahankan oleh pasukan Manchu yakni provinsi Honan dan provinsi Chihli. Para pasukan revolusioner menuntut agar kaisar terakhir Dinasti Manchu yakni Yuan Shi Kai untuk turun tahta. Akhirnya keruntuhan Dinasti Manchu tidak dapat terelakan. Tepat pada 29 Desember 1911, kaum revolusioner mengangkat Dr. Siun Yat Sen sebagai presiden pemerintah yang pertama untuk Republik China. ${ }^{28}$

Setelah berhasil menaklukkan Dinasti Manchu dengan gerakan Revolusi China yang ia galang, Dr. Sun Yat Sen ingin merealisasikan cita-citanya yang dikenal dengan istilah San Min Chu I (Tiga Asas Rakyat). Adapun ketiga asas rakyat yang dimaksud adalah: Pertama, "Min Tsen" yang memiliki arti nasionalisme. Azas pertama ini ia menghendaki adanya satu bangsa serta satu negara yakni bangsa China sebagai satu kesatuan yang utuh. Kedua, "Min Chu" yang artinya demokrasi. Ia berharap bahwa kedaulatan tertinggi negara China berada di tangan rakyat. Dengan ini ia menginginkan wajah baru di negeri tersebut yaitu negara republik yang demokratis. Ketiga, "MinSheng" yang artinya sosialisme. Dengan asas ini, Dr. Sun Yat Sen ingin menjadikan asas sosialisme sebagai asas kehidupan bangsa China. Ia juga berharap dengan mengadopsi falsafah ini, masyarakat China dapat mencari dnafkah serba layak untuk memenuhi kebutuhanya. Namun gagasan revolusionernya tersebut harus terhenti karena Dr. Sun Yat Sen

\footnotetext{
${ }^{27}$ Lihat dan bandingkan Riedha Faridha and Nor Huda, 'Islam Di Cina Pada Masa Pemerintahan Republik Nasionalis, 1911-1949', Tamaddun, 14.2 (2015), 156.

${ }^{28}$ Leo Agung S, Sejarah Asia Timur 1 (Yogyakarta: Ombak, 2012). 79-81.
} 
hanya mampu memegang jabatan presidenya sekitar tiga bulan, selanjutnya jabatan ia serahkan kepada Jenderal Yuan Shi Kai. ${ }^{29}$

Meski pemimpin Revolusi Dr. Sun Yat Sen tidak dapat mempertahankan jabatanya dalam kurun waktu yang lama. Namun dengan diangkatnya Dr. Sun Yet Sen sebagai presiden pertama dari Republik Demorasi China pasca revolusi menunjukkan bahwa masyarakat China pada masa itu telah mengakui kontribusi salah satu tokoh besar Islam tersebut. Selain itu, perjuangan Dr. Sun Yat Sen juga menunjukkan kepada kita bahwa umat Islam selalu terlibat aktif untuk perkembangan dan kemajuan negeri China. Oleh karena itu, keberadaan umat Islam di China tidak dapat dipandang sebelah mata. Karena pencapain besar atas negeri China tidak lepas dari kontribusi dan keterlibatan umat Islam yang ikut serta membangun China melalui sejarah panjang dimasa lalu.

Sungguh sangat memprihatinkan ketika umat Islam di China yang selalu hadir dalam membangun peradaban bangsa tersebut harus kembali menelan pil pahit untuk yang kesekian kali ketika China berhasil dikonversi menjadi negeri Komunis. Kaum komunis yang berhasil merebut kekuasaan pemerintah di akhir tahun 1940-an benar-benar telah menyempurnakan pengawasanya terhadap Masyarakat Muslim di China. Mereka telah menghapuskan wakaf yang diwariskan ke masjid-masjid dan lembaga-lembaga keagamaan Islam lainya. Kondisi tersebut sangat memukul umat Islam China dan berpengaruh besar terhadap tatanan kultur sosial, ekonomi, politik serta budayanya. Bahkan kaum komunis juga menggantikan huruf Arab yang sudah menjadi ciri khas dan budaya muslim di Sinking dan Kansu menjadi huruf Cyrillik. Kita tentu dapat membayangkan bagaimana dua deminse budaya tersebut digerus habis oleh kaum komunis China. Tidak luput pajak untuk membiayai sekolah-sekolah muslim juga ikut dihapus. Bahkan dalam urusan menjalankan syariat Islam, mereka

\footnotetext{
${ }^{29}$ Kematian Yuan Shi Kai banyak meninggalkan masalah bagi negeri China. Ambisi untuk menguasai China secara utuh yang ia lakukan dengan pendeklarasian kaisar atas dirinya sendiri mengakibatkan beberapa provinsi melepaskan diri dan meminta otonominya. Lihat, Leo Agung S, Sejarah Asia Timur 2 (Yogyakarta: Ombak, 2012). hal.4. Bandingkan juga dengan Ceren Ergenc, 'Chinese Nation-Building and Sun Yat Sen A Study on 1911 Revolution in China' (Ankara: The Graduate of Social Sciences: Middle East Technical University, 2005)., hal. 28.
} 
berusaha ikut campur dengan mengeluarkan peraturan yang melarang pegawai negeri/pejabat pemerintah untuk menjalankan puasa. $^{30}$

\section{Kehidupan Sosial Umat Islam di China}

Secara garis besar, umat Islam di China dapat dikelompokkan menjadi tiga kelompok kebangsaan utama yaitu: Turki yang terdiri dari orang-orang Uyghur, Kirghiz, Kazakh, Uzbek dan orang-orang muslim percampuran antara bangsa Salar dan Hicu. Uyghur sendiri merupakan kelompok inti penduduk muslim yang ada di Turkestan Timur. Penduduk pribumi atau nonIslam sering memanggilnya dengan sebutan Hui Hui, sementara Tajik merupakan sebutan bagi muslim lainya yang menggunakan bahasa Persi. Terdapat pula muslim Mongol, Lolo, Sihia, Tao dan juga Tibet yang merupakan bagian minoritas dari Muslim China. Meski demikian, orang-orang Islam di China sendiri lebih suka menyebut mereka dengan sebutan Chew-Min, sementara agamanya disebut dengan Tsing Ching Chew yang artinya "agama yang suc". 31

Pasca revolusi China, mereka berusaha untuk mempertemukan antar berbagai golongan bangsa dan membentuk persatuan diantara masyarakat China. Orang muslim sendiri tidak bisa lepas dari kebudayaan Hang yang sudah mengakar kuat dalam tradisi China. Meski demikian dalam hal perkawinan, nilai moral, makanan dan etika sosial tetap pada batasan-batasan agama Islam. Tidak ditemukan perkawinan campuran antara muslim dengan non-muslim, bahkan untuk bisa menikahi seorang perempuan nonmuslim (yang menurut hukum syari diperbolehkan), adat masyarakat muslim China tetap mengharuskan calon mempelai perempuan untuk masuk agama Islam terlebih dahulu. Apabila hal

\footnotetext{
${ }^{30}$ Larangan berpuasa ini dilakukan pemerintah kepada penduduk muslim Uyghur, Provinsi Xinjiang China dengan berbagai cara. Mulai dari tetap membiarkan toko makanan buka pada bulan ramadan, menambah porsi jam olah raga di sekolah pada siang hari, hingga peraturan pemerintah yang tidak memperbolehkan pegawai negeri atau pekerja sekotor pemerintahan untuk berpuasa dengan alasan dapat mengurangi produktifitas kerja. Lihat, 'Kacau Otoritas China Larang Umat Muslim Uighur Berpuasa' <https://news.okezone.com/read/2017/06/06/18/1708975/kacau-otoritaschina-larang-umat-muslim-uighur-berpuasa>

${ }^{31}$ M. Rafiq Khan, Islam Di Tiongkok (Jakarta: Tintamas, 1967). 30.
} 
itu tidak dilakukan maka pernikahan juga tidak akan pernah berlangsung. ${ }^{32}$

Memang pada dasarnya masyarakat muslim China cenderung hidup komunal yang terpisah dari penduduk yang memiliki kepercayaan yang berbeda, baik itu ketika mereka tinggal di kota maupun di desa. Meski demikian, mereka selalu berusaha untuk menjaga sikap agar terhindar dari sifat pamer atau melakukan konfrontasi yang sekiranya dapat menyulut/menyinggung perasaan penganut agama lain. Umat Islam China biasanya juga membuat kampung-kampung khusus untuk mereka. Dan bagi orang-orang Han, sangat mudah untuk mengenali rumah-rumah orang Muslim karena mereka memiliki konsep bentuk rumah yang berbeda. ${ }^{33}$

Kehidupan sehari-hari masyarakat muslim China sepenuhnya adalah kebiasaan dan tata cara kehidupan masyarakat setempat seperti halnya rambut panjang yang dikucir khas ala masyarakat China. Tradisi ini sudah ada sejak zaman Dinasti Manchu dan mereka masih menggunakan sebagian besar kebiasaaan tersebut hingga masa kini. Cara berpakain juga tidak jauh berbeda dengan masyarakat China non-muslim pada umumnya. Yang membedakan, umat Islam China akan menggunakan tambahan sorban ketika hendak pergi ke masjid. ${ }^{34}$

Keadaan yang sebaliknya terjadi pada umat Islam Uyghur dari Sinkiang (Xinjiang) dan umat Islam Kazakh dari daerah barat laut China. Mereka yang tinggal di daerah tersebut umumnya memiliki kebiasaan berpakaian yang berbeda dengan masyarakat China pada umumnya. ${ }^{35}$ Di bagian barat laut, para wanita muslim menggunakan cadar atau penutup muka apabila mereka hendak

\footnotetext{
${ }^{32} \mathrm{Ibid}, 16-17$

${ }^{33}$ Dawoud C.M Ting, Kebudayaan Islam Di China (Jakarta: Pustaka Jaya, 1980). 398.

${ }^{34}$ Thomas W Arnold, Sejarah Dakwah Islam (Jakarta: Widjaya, 1979). 26.

${ }^{35}$ Perbedaan tradisi dan gaya hidup ini yang membuat muslim Uyghur sering diasosiasikan dengan keinginan Muslim Uyghur yang ingin memisahkan diri dari pemerintah China. Oleh karena itu, akhir akhir ini kita sering melihat tindakan agresif dari pemerintah China kepada umat Islam Uyghur di Xinjiang China (begitu juga sebaliknya). Baca, Baiq L.S W and Wardhani, 'Respon China Atas Gerakan Pan-Uyghuris Di Provinsi Xinjiang', Masyarakat Kebudayaan Dan Politik, 24.4 (2011). 295-296.
} 
melakukan aktifitas di luar rumah. Sementara itu di beberapa daerah para wanitanya juga mengenakan sorban dan para kaum laki-lakinya menggunakan tutup kepala yang berwarna putih dan lebar. Di daerah Xinjiang, kaum muslim laki-laki menggunakan penutup kepala berukuran kecil yang berwarna-warni serta bersulam. Ada juga yang menggunakan sorban dari bahan katun berwarna putih dan kuning. Sedangkan di beberapa daerah Xinjiang yang lainya, kaum laki-laki muslim menggunakan peci (kufiah) ketika menunaikan shalat jumat. Adapun pemakaian sutera hanya diperuntuhkan bagi para perempuan muslim dan laki-laki yang dianggap sebagai pemuka agama. ${ }^{36}$

Islam dengan tegas melarang umatnya untuk memakan beberapa jenis makanan tertentu. Aturan ini juga diterapkan oleh masyarakat muslim di China dengan cara berhati-hati dalam memilih makanan. Mereka tidak memakan daging babi, darah, bangkai, hewan persembahan serta hewan-hewan yang diharamkan lainya. Mereka juga menghindari mengkonsums rokok, araka dan opium (candu). Rumah makan halal juga banyak dibangun disana dengan tidak menyediakan masakan berbahan daging babi. Sementara itu arak masih tetap tersedia untuk kalangan orang nonmuslim dan mereka akan memisahkan cangkir-cangkir yang digunakan untuk menuang arak dengan cangkir yang digunakan oleh orang Islam. Tidak cukup sampai disitu, mereka juga mempunyai kedai, toko roti dan parfum yang tidak mengandung alkohol atau obat-obatan yang tidak diperbolehkan oleh Islam. Umat Islam di China juga terkenal ulet dalam bidang perekonomian dan dagang seperti halnya masyarakat pribumi pada umumnya. $^{37}$

Karena terlalu lama putus hubungan dengan dunia luar secara tidak sadar umat Islam China telah membuat mereka menjadai sedikit terpengaruh oleh ajaran konfusianisme dan Budhisme dalam beberapa hal. Diantaranya dalam hal penyebutan tempat ibadah yang menggunakan kata syih yang berarti masjid. Kata syih sendiri merupakan penyebutan kuil bagi agama Budha. masjid-masjid yang ada di China juga memiliki kemiripan dengan kuil Kong $\mathrm{Hu}$ Chu dan kuil Budha apabila diamati dari luar.

\footnotetext{
${ }^{36}$ Faridha and Huda. Op.cit, hal.17.

${ }^{37}$ Ting. hal. 399-340. Lihat juga, Arnold. Op.cit, hal. 270
} 
Karena pada masa kekaisaran Manchu, tidak diperbolehkan masyarakatnya membangun diluar bentuk bangunan yang lumrah pada zamanya. ${ }^{38}$

Sikap Dinasti Manchu yang terang-terangan memusuhi umat Islam China menyebabkan keterbelakangan dan kesengsaraan banyak hal bagi kaum Muslim China. Meski demikian, imbas dari tindakan represif dari Dinasti Manchu ini tidak dialami oleh umat Islam secara keseluruhan. Terdapat daerah-daerah dimana umat Islam yang tinggal di pedalaman atau terpencil jauh dari pusat kota hidup dalam situasi yang biasa saja. Pasca revolusi nasionalis, para revolusioner bergerak untuk menjangkau mereka guna memperbaiki kehidupan mereka yang lebih baik lagi. Pada dasarnya mereka tidak dapat dikatakan ketinggalan apabila dibandingkan dengan masyarakat yang hidup di daerah dekat dengan peradaban kota. Bahkan mereka memiliki posisi yang cukup strategis dalam perdagangan, pertanian dan peternakan. Mungkin karena Tiga Asas Rakyat (San Min Chu I) yang diusung oleh Dr. San Yet Sen ketika melakukan revolusi yang membuat pemerintah merasa perlu untuk memperhatikan dan tidak membiarkan seorangpun masyarakatnya yang tidak terjamah oleh pemerintah. ${ }^{39}$

Apabila melihat kehidupan sosial masyarakat Islam di China, terlihat jelas bahwa mereka dapat membaur dengan budaya masyarakat setempat. Mereka tetap menjunjung tinggi adat istiadat yang ada, disamping mereka tetap berusaha menjalankan perintah agama. Akulturasi budaya semacam ini hanya dapat kita temukan di daerah-daerah yang menerima Islam melalui cara damai. Tidak seperti penyebaran Islam di kawasan Timur Tengah yang menggantikan budaya setempat (pribumi) dengan budaya Arab, Islam di China lebih luwes dan mampu menyesuaikan diri dengan situasi rezim pada masanya. Alasan inilah yang sekiranya membuat Islamtetap eksis hingga saat ini di negeri yang berpaham komunis (China yang sekarang) meski dengan jumlah yang minoritas.

\footnotetext{
${ }^{38}$ Arnold. Ibid

${ }^{38}$ Lihat dan bandingkan, Ibid, 18.Bandingkan juga dengan Ergenc. Op.cit, hal.399-340.

${ }^{39}$ Lihat dan bandingkan, Ibid, 18.Bandingkan juga dengan Ergenc.Op.cit, hal. 28.
} 


\section{Perkembangan Pendidikan Islam di China}

Pasca revolusi yang digaungkan oleh Sun Yat Sen, umat Islam kembali mendapatkan kebebasan untuk ikut dalam kursi pemerintahan Republik China. Mereka berusaha untuk membangun kembali posisi dan kedudukan mereka yang sempat dirampas dan stagnasi selama Dinasti Manchu berkuasa. Salah satu perkembangan pesat adalah dalam dunia pendidikan.

Sistem pendidikan Muslim di Negeri Tirai Bambu pada umumnya sama dengan pendidikan di wilayah muslim lainya. Pada mulanya pendidikan agama berkonsentrasi pada masjid-masjid dengan menggunakan sistem halaqah atau masyarakat muslim China lebih mengenalnya dengan sebutan Jingtang Jiaoyu. Sistem ini merupakan sistem pendidikan yang dikembangkan oleh masyarakat Muslim China selama periode kekuasaan Dinasti Ming dan Hui yang menjadikan masjid-masjid sebagai pusatnya. Bahasa Arab serta Persia merupakan bagian dari kurikulum utama dalam sistem pendidikan Islam di China. Bahasa Persia sendiri merupakan bahasa asing Islam utama yang digunakan oleh masyarakat muslim China dan diikuti oleh bahasa Arab. Beberapa jenderal muslim juga ikut membiayai atau menjadi sponsor siwa muslim utuk belajar ke luar negeri. ${ }^{40}$

Sistem pendidikan Islam di China juga sangat familiar dengan beberapa literatur China muslim seperti Kitab Han. Seorang ulama bernama Liu Zhi menulis teks yang bertujuan untuk membantu orang-orang Islam di China belajar bahasa Arab. Sementara itu, kamus Arab-Tionghoa merupakan kamus pertama yang disusun oleh Shaik Elias Wong Ching pada tahun 1925 yang diterbitkan di Tientsin. Selain membuat kamus, ia juga gigih dalam menerjemahkan al-Quran dari bahasa Arab ke China. ${ }^{41}$

Pada masa Republik China, pemerintah mendukung Akademi Guru Chengda yang membantu mengatur era baru dalam pendidikn Islam di China. Mereka memperkenalkan semangat nasionalisme dan bahasa Cina dikalangan umat Islam serta menggabungkan sepenuhnya ke dalam aspek utama masyarakat China. Bahkan perhatian pemerintah China pada masa itu terhadap pendidiakn Islam sangat besar. Terbukti pemerintah pada masa itu

${ }^{40}$ Faridha and Huda.Op.cit, hal.19.

${ }^{41}$ Ma.Op.cit., hal. 329. 
sengaja menyediakan dana untuk Federasi Keselamatan Nasional Islam China untuk pendidikan Islam di negeri tersebut. Adapun presiden federasi tersebut dijabat oleh Jenderal Bai Chongxi (Pai Chung-his) dan wakilnya yaitu Tang Kesen (Tang Ko-San). sekolah dasar Sino-Arab juga didirikan di Ningxia oleh gebernurnya yakni Gubernur Hongkui. ${ }^{42}$

Pada perkembangan selanjutnya, sisitem pendidikan yang sederhana secara perlahan tapi pasti mulai menuju perguruan tinggi yang bersifat lebih modern. Revisi dilakukan pada buku-buku Islam. Umat Islam di China juga mulai mengenal pendidikan modern namun masih bersifat swasta. Adapun biaya yang diperlukan untuk keberlangsung institusi-institusi pendidikan ini menggunakan biaya sendiri tanpa ada ikut campur dari pemerintah. Adapun salah satu tokoh muslim China yang terkenal gigih membantu proses pembangunan pendidikan di China adalah Muhammad Ma Jian (Muhammad Makin, 1906-1978 M). Dia adalah seorang sarjana Islam China sekaligus penerjemah dari Provinsi Yunnan dari China Barat Daya. ${ }^{43}$

Daerah yang menjadi basis penduduk Muslim juga menjadi tempat dimana banyak perguruan tinggi Islam lahir. Begitu juga dengan sekolah lanjutan seperti Now West College yang berdiri di Peking, Ming The Secondary School yang ada di Provinsi Yunnan, $M u$ Sing Secondary Scool di Chinghai, Kun Loon Middle School di Chinghai dan Cheng Ta Islamic Normal School di Tsianan dan Peking. Serta Kang Chow yang terletak di Provinsi Kansu pernah menjadi kiblat utama pengkajian Islam hingga tahun 1928. Namun dalam aksi serangan yang dilakukan oleh Fang Yu Hiang menyebabkan banyak kerusakan sehingga dengan terpaksa pusat kajian Islam pindah ke Peking. ${ }^{44}$

Berdirinya sejumlah perguruan tinggi di Peking tidak dapat dilepaskan dari peran tokoh muslim yang cukup disegani yaitu Jenderal Ma Fo Hiang. Karena kegigihanya, dia mendapat bantuan dari pemerintah yang ada di Peking guna membangun pendidikan di wilayah tersebut. Jenderal tersebut setidaknya telah membangun 12 tempat pendidikan di sekitar masjid-masjid. Oleh karena itu

\footnotetext{
${ }^{42}$ Faridha and Huda.Op.cit, hal.19

${ }^{43}$ Ma. Op.cit, hal. 256.

${ }^{44}$ Faridha and Huda.Op.cit. hal., 20.
} 
ketika ada rencana pemindahan college dari Tsinan ke Peking, Ma Fo Hiang sangat menyambut rencana tersebut bahkan biaya bulanan di college ditanggung oleh keluarganya serta orang-orang muslim kaya yang ada di Peking. Terdapat sebuah catatan dari Badarudin Chini (1935 M) yang menyebutkan bahwa sistem pendidikan college di Peking sangat maju dengan pembagian tiga kelompok study yaitu: kelompok remaja/junior, madya/senior dan kelompok umum. ${ }^{45}$

Selain Jenderal Mang Fo Hiang, terdapat tokoh Islam lainya yang berusaha untuk membangun lembaga pendidikan Islam di daerah Peking. Sebagai contoh Shaik Muhammad Wang Hao Jan yang membangun sekolah dasar (Primary Muslim School) pada tahun 1910 M. Ada juga Shaik Nur Muhammad Ta Pu Sheng pimpinan dari perguruan tinggi Madrasah Muallimin (Islamic Normal School) yang berdiri pada tahun 1928 M. Dari Madrasah Muallimininilah Muahammad Ma Chien (Makin) dikirim ke Mesir untuk menuntut ilmu. Selain itu, ada juga beberapa orang yang dikirim seperti H. Abubakar F. T. Hu dan Dawoud C.M. Ting. Selain Madrasah Muallim, Madrasah Muallimin Wan Hsien (Hsein Islamic Normal School) juga pernah mengirimkan beberapa utusan pelajarnya untuk menimba ilmu ke Mesir. ${ }^{46}$

Meski sejatinya sekolah-sekolah tersebut diperuntuhkan bagi umat Islam, namun untuk pelajaran matetamtika, fisikia, hitorgeografi dan beberapa ilmu terapan lainya yang bersifat umum tetap diajarkan oleh guru-guru yang berkompeten di bidangnya tanpa mempermasalahkan latar belakang keagamaan mereka. Pelajaran tentang prinsip dan administrasi edukasi, psikologi etika dan civis diajarkan pada tingkat perguruan tinggi. Ada juga $M u$ Hsin Midle School (Sekolah Menengah Pembaharuan Islam) yang terletak di Hankow, provinsi Chekiang yang berdiri pada tahun 1928 M. Hebatnya tidak hanya menampung pelajar muslim, nonmuslim juga dapat ikut menimba ilmu di lembaga pendidikan ini. ${ }^{47}$

Imbas dari pesatnya perkembangan pendidikan Islam yang di rintis oleh tokoh-tokoh muslim China ini adalah banyaknya karya tulis atau kolom tulisan yang menampung karya tulis tentang

\footnotetext{
${ }^{45}$ Khan. Op.cit, hal.40.

${ }^{46} \mathrm{Ma}$. Op.cit, hal. 322.

${ }^{47}$ Ibid, 334.
} 
pemikiran Islam. Tulisan yang dimuat dalam jurnal-jurnal tersebut tidak hanya menambah khasanah keilmuan, lebih dari itu, karyakarya tersebut bahkan mampu mempengaruhi arah gerak pemikiran masyarakat muslim China. Berikut beberapa kolom jurnal yang memiliki banyak pengaruh terhadap pemikiran muslim di China: Islamic Journal (Berkala Islam) yang terbit di Yunnan pada tahun 1911, Islamic Literature (Kesusteraan Islam) terbit di Peking. Selanjutnya ada Domestic Education terbit di Katon pada 1912 M, The Journal of The Muslim Youth, The Islamic Community dan masih banyak lagi. ${ }^{48}$ Kolom-kolom jurnal tersebut sangat penting bagi masyarakat Islam. Tema tulisan yang terbit biasanya berisi tentang gagasan dan pandangan-pandangan umat Islam tentangkeislaman dan kemajuan.

Perkembangan pendidikan Islam di China selain dapat ditelusuri melalui lembaga-lembaga pendidikan dan journal/majalah Islam yang menginspirasi, selama Islam mewarnai beberapa dinasti yang ada di China hingga masa revolusi terdapat para tokoh cendikiawan terkenal karena pencapaian bidang akademiknya diantaranya adalah: Dalam bidang Sastra adaLee Yen Shen, Lee Hsuin dan Lee Shun mereka terkenal sebagai cendekiawan dalam bidang Sastra, pada masa kekaisaran Dinasti Tang. Selanjutnya ada Wang Daiju (1584-1670), dia adalah pencipta dari teori pembela Islam dengan membedakan dengan budaya China. Ia juga sangat mahir dalam bidang studi pengetahuan klasik China dan telah menyebarkan inti dari ajaran Islam kepada masyarakat China. Tidak bisa dipungkiri, pemikiran Wang Daiyu banyak mempengaruhi umat Islam sepanjang sejarah. Adapun karya-karya monumentalnya yang terkenal hingga kini adalah True Explanation on The Right Religion (Islam), High Learning in Qing Zhen (Islam). ${ }^{49}$

Yusuf Ma Zhu (1640-1711 M), dia lahir di daerah Yunnan. Magnum opus beliau yang fenomenal adalah Direction in Islam yang bersinggungan dengan sejarah Islam, falsafah serta undang-undang yang menitik beratkan bahwa Islam harus difahami dengan mengenal nama-nama sifat Allah sebagai landasan utama ilmu pengetahuan. Ia juga menggagas prinsip-prinsip Islam sebagai salah

\footnotetext{
${ }^{48}$ Tercatat lebih dari 20 kolom jurnal yang terkenal pada waktu itu dan secara berkala menerbitkan gagasan tentang Islam.Lihat, Ibid, 36.

${ }^{49}$ Asmanidar. Op.cit., hal.205.
} 
satu yang sangat penting dalam memperbaiki tatanan sosial yang berazaskan keadilan dan kesejahteraan masyarakat. ${ }^{50}$

Lin Zhi (1665-1745 M) adalah seorang cendikiawan terkemuka yang lahir di daerah Nanjing. Karya monumentalnya yang terkenal adalah Tian Fang Jian Li (Etika dalam Islam). Karya tersebut menjadi karya satu-satunya yang dikumpulkan dalam ensiklopedia (Si Ku Quan Shu) serta memiliki daftar rujukan yang sangat terpercaya pada zaman Dinasti Qing/Manchu. Oleh karena itu, di masyarakat China clasik, ia dikenal sebagai cendekiawan yang sangat membanggakan dalam memahami pespektif Islam yang lebih mendalam. ${ }^{51}$

YusufMa Dexin (1794-1874 M), ia dikenal karena kefasihan dan kemahiranya dalam sastra Arab, Persi dan pengetahuan Islam yang sangat luas lainya. Ia pernah menerjemahkan al-Quran ke dalam bahasa China serta menulis beberapa buku tentang Islam dalam bahasa Arab dan Persi. Karena di tuduh terlibat dalam pemberontakan Yunnan Islam, ia di eksekusi oleh rezim Dinasti Qing/Manchu. Adapun karya-karya monumentalnya adalah The True Revealed Scripture, Nabwu wa Saierfu (berbahasa Arab), Universal Description dan Huan Yu Shu Yao (maklumat kalender Islam). ${ }^{52}$

Terdapat banyak nama-nama cendekiawan muslim China selain yang sudah disebutkan diatas seperti: Macsuddin, Yabuddin dan Bermaludin mereka mendapatkan kemasyhuran karena karyakarya mereka tentang sejarah Dinasti Yuan. Janeddin (konsentrasi mempelajari ajaran Kong $\mathrm{Hu} \mathrm{Chu}$ ), Sabtullah dan Kao Keh Kong (pelukis yang terkenal), Din Hao Nien (seorang penyait yang terkemuka), Isa (ahli farmasi), Ma Kin Kao (kaligrafis huruf China primitif dan sekaligus seorang komponis musik, Hu Poo Chao (Hussain A. Rahim)- ahli pendidikan, Yahader/Bakbtiar (arsitek yang merancang istana Tai Tu, nama ibukota Peking pada masa Dinasti Yuan dan kota-kota terkenal lainya di timur jauh), Kai Chi (seorang pelukis), Ming Loong dan Wang Tai Yu (ahli kesenian) dan masih banyak lagi. ${ }^{53}$

\footnotetext{
${ }^{50}$ Ibid, 206.

51 Ibid.

52 Ibid.

${ }^{53}$ Ma. Op.cit, hal. 268-269.
} 
Perkembangan pendidikan Islam di China telah melahirkan banyak cendekiawan, lembaga-lembaga pendidikan dan pemikiran orisinil yang tidak hanya bermanfaat bagi masyarakat muslim China namun juga bagi perkembangan budaya China secara keseluruhan. Meski beberapa kali umat Islam China mendapatkan tekanan dari Dinasti yang berkuasa saat itu, namun dengan kegigigan dan semangat belajarnya tidak mengurangi niat mereka untuk tetap mengembangkan ilmu pengetahuan. Bahkan sebagian dari mereka rela menyisihkan harta kekayaanya untuk membangun dan membiayai lembaga-lembaga pendidikan Islam yang sering kali tidak mendapat respon dari penguasa pada saat itu.

Sistem pendidikan yang diterapkan umat Islam juga menunjukkan adanya sebuah langkah progresif dari waktu ke waktu. Hal ini terlihat jelas ketika perkembangan awal pendidikan Islam di China masih memanfaatkan masjid sebagai tempat utama untuk saling tukar pengetahuan (atau yang sering disebut halaqab). Model halaqah dengan memanfaatkan masjid sudah menjadi ciri khas pendidikan Islam di abad pertama berdirinya Islam. Dengan kondisi politik yang fluktuatif bagi umat Islam China, secara mengejutkan mereka mampu meningkatkan model sistem pendidikan yang lebih modern yaitu model sistem pendidikan perguruan tinggi mengikuti perkembangan zaman modern pada masa itu. Untuk yang kesekian kalinya, dalam sektor pendidikan umat Islam China berhasil membuktikan bahwa dengan jumlah minoritasnya mereka tetap survive tidak hanya untuk menegakkan panji-panji Islam namun juga untuk masa depan China yang lebih gemilang.

\section{Kesimpulan}

Setidaknya terdapat dua pendapat tentang sejarah awal masuknya Islam di China. A. Berlie berpendapat Islam pertama kali masuk ke China pada abad ke-8 melalui jalur perdagangan. Namun pendapat yang lebih kuat menyebutkan bahwa Islam pertama kali masuk ke China sekitar abad ke-7. Berdasarkan catatan resmi dari Dinasti Tang dan tulisan Chen Yuen, Khalifah Utsman bin Affan pernah mengirim utusanya ke China pada tahun 30 H/651 M tepatnya pada pemerintahan Kaisar Yong Hui. Sementara itu berdasarkan teori model penyebaran dan tahapan 
masuknya Islam ke China, semua teori menunjukan bahwa Masuknya Islam ke China tidak melalui jalur peperangan (invasi) melainkan melalui jalur perdagangan dan perkawinan. Corak penyebaran Islam yang seperti ini berpengaruh terhadap karakteristik umat Islam di China yang lebih mudah menerima dan beradaptasi dengan budaya setempat (fleksibel).

Pada perkembangan selanjutnya, umat Islam mengalami tekanan yang luar biasa hebat pada masa kekaisaran Dinas Manchu/Qing (1644-1912 M) dan ketika China di kuasai oleh kaum komunis pada akhir tahun 1940-an. Hanya dalam kurun waktu 12 tahun, pemerintah tiran Manchu telah membunuh tidak kurang dari 2 juta umat Islam. Tekanan demi tekanan yang dialami Umat Islam memaksa tokoh Muslim Sun Yat Sen untuk menggaungkan revolusi guna menjatuhkan Dinasti Manchu. Keberhasilan Sun Yat Sen dalam meruntuhkan dominasi Dinasti Manchu tidak hanya memberikan harapan kepada umat Islam namun juga bagi seluruh rakyat China. Karena atas jasa besarnya, China berubah menjadi negara republik yang demokratis sebelum kaum komunismenguasai China di akhir tahun 1940-an. Sedangkan pada masa kepemimpinan kaum komunis, pemerintah menghapus seluruh tanah waqaf masjid dan biaya sekolah untuk umat Islam yang sebelumnya sudah dianggarkan.

Sementara itu untuk kulturbudaya dan sosial, umat Islam di China berusaha untuk mengintegrasikan antara kebudayaan pribumi dengan tuntutan kehidupan beragama yang sesuai dengan syariat Islam. Mereka sangat menjaga norma-norma agama Islam seperti tidak minum arak, makan daging babi dan menikah dengan orang no-muslim. Meski demikian, mereka sangat menjunjung tinggi budaya pribumi. Tercatat, hanya Muslim dari Uyghur dan Khazak yang memiliki cara berpkaian yang berbeda dengan penduduk asli pribumi. Sementara itu dalam bidang pendidikan, umat Islam di China mampu mengembangkan pendidikan hingga mampu mendirikan perguruan tinggi. Imbas dari langkah progresif itu adalahbanyakpara cendekiawan muslim China yang lahirkan dari lembaga-lembaga tersebut, serta memberikan kontribusinya bagi negeri China. 


\section{DAFTAR PUSTAKA}

Arnold, Thomas W, Sejarah Dakwah Islam (Jakarta: Widjaya, 1979)

Asmanidar, 'Potret Tamaddun Islam Di Negeri Tirai Bambu: Mulai Dari Masa Dinasti Tang Hingga Republik China', Jurnal Ilmiah Islam Futura, 14 (2015), 195

Berlie, Jean A, Islam in China: Hui and Uygghurs Between Modernization and Sinicization (Bangkok: White Lotus, 2004)

Broomhall, Marshall, Islam in China: A Negletged Problem (New York: Paragoon Book Reprint Corp, 1966)

Ergenc, Ceren, 'Chinese Nation-Building and Sun Yat Sen A Study on 1911 Revolution in China' (Ankara: The Graduate of Social Sciences: Middle East Technical University, 2005)

Faridha, Riedha, and Nor Huda, 'Islam Di Cina Pada Masa Pemerintahan Republik Nasionalis, 1911-1949', Tamaddun, 14 (2015), 156

Hall, D.G.E, Sejarah Asia Tenggara (Surabaya: Usaha Nasional)

Israeli, Raphael, Islam China (United States of America: The Lexington Books, 2002)

'Kacau Otoritas China Larang Umat Muslim Uighur Berpuasa' <https://news.okezone.com/read/2017/06/06/18/1708975 / kacau-otoritas-china-larang-umat-muslim-uighur-berpuasa $>$

Khan, M. Rafiq, Islam Di Tiongkok (Jakarta: Tintamas, 1967)

Ma, Ibrahim Tien Ying, Perkembangan Islam Di Tiongkok (Jakarta: Bulan Bintang, 1979)

S, Leo Agung, Sejarah Asia Timur 1 (Yogyakarta: Ombak, 2012)

—, Sejarah Asia Timur 2 (Yogyakarta: Ombak, 2012)

Seng, Aan Wang, Biar Orang China Pimpin Islam (Selangor: Kemilau Republika, 2011)

_- Rahasia Kegemilangan Islam Di China (Selangor: LA Khauf Marketing, 2007)

Ting, Dawoud C.M, Kebudayaan Islam Di China (Jakarta: Pustaka 
174 ljtimaiyya: Jurnal Pengembangan Masyarakat Islam 10 (1) (2017)

Jaya, 1980)

W, Baiq L.S, and Wardhani, 'Respon China Atas Gerakan PanUyghuris Di Provinsi Xinjiang', Masyarakat Kebudayaan Dan Politik, 24 (2011)

Wekke, Ismail Suardi, 'Antara Tradisionalisme Dan Kemodernan: Pembelajaran Bahasa Arab Madrasah Minoritas Muslim Papua Barat', Tsaqafah, 11 (2015), 313-32

'Religious Education and Empowerment: Study on Pesantren in Muslim Minority West Papua', Miqot, XXXVII (2013), 374-95

Wekke, Ismail Suardi, and Sanusi Hamid, 'Technology on Language Teaching and Learning: A Research on Indonesian Pesantren', Procedia - Social and Behavioral Sciences, 83 (2013), 585 